\title{
Orthodox icon, medium and the mystical way of communion of man with God through the Holy Spirit
}

\author{
Part I: In the beginning was the Icon
}

\section{Emanuel Sorin BUGNER*}

Abstract: The icon is a common heritage of the western and eastern church. In the western and Protestant church it does not play a special role, but only an aesthetic one. The icon is and represents a complex theology because in the eastern church the meaning of the icon is not limited to the historical or aesthetic aspects. People should understand that an icon doesn't have an ornamental role because it reveals us the truth of God. The eastern tradition confirms that the icon was from the beginning an important part of our former confession and even apostle Lukas has painted an icon. Many other deliverances mention the existence of a former cult of the Christians also including the icons. The gospel of Jesus had to be proclaimed. But how? We should now think of the people who were not able to read because for them the icons played a special role. When someone looks at an orthodox icon he can easily recognize that the most important task of the painter was not the color or the appearance of the image but the proclamation of the word of God and his true teachings. An orthodox icon does not show how great, beautiful or powerful the body of a Saint was, also not what kind of colors the painter has used but the faith, the humility and holiness of the Saint. Therefore there are no

* Dipl.-Ing. Mag. Dr. Pr. Emanuel Sorin Bugner, Last Publication: Libertate sau minciună?, Deisis, Revistă de Cultură şi Spiritualitate, edited by Mitropolia Ortodoxă Romană pentru Germania, Europa Centrală şi de Nord, Nr.21/2013. 
statues in the cult of the orthodox church. The early Christians who went to a church or had an icon at home had the best opportunity to get to know the real life of the depicted Saints and to take them as a model and to follow them in faith. In the orthodox church there are several essential functions of the icon. The most important functions of an icon in the orthodox church are: liturgical, pedagogical, theological and artistic. Most orthodox believers have icons at home often arranged in a corner in the living room at the eastern wall. One day God will appear in the East to judge the world.

Keywords: Icon, Salvation, Holiness, Idol, Dogma, Prayer

\section{A brief look at the historicity of icon}

After the foundation of the early Church, although the image of Him, who incarnated, suffered, rose again and ascended into heaven, was still fresh in the memory of his disciples, the need to represent the holy persons into visible forms makes us understand that the religious life of the first Christians possessed a visual language. ${ }^{1}$

The researchers' opinions concerning the existence of iconographic material in the first three centuries of Christian worship are divided. Thus, according to the French scientist Gibon (1737-1792) the hypothesis that early Christians possessed a deep aversion to images would be viable (given the unchanged conception of Jewish converts and their sensitivity to pagan influences) attitude born from their desire to avoid any form of idolatry that could alter their new religious orientation. Because of this, says the scientist, first icons could not occur sooner than the $4^{\text {th }}$ century. ${ }^{2}$ A similar information is supported by Th.Klauser, saying that "Christian art was born outside the Church" and "on the initiative of the believers", the church accepting it by

1 I. Rămureanu, Cinstirea sfintelor icoane în primele trei secole, în rev. „Studii Teologice”, nr. 9-10, 1971, p. 622. Nicolae.V. Dură, Teologia icoanelor in lumina tradiţiei dogmatice şi canonice ortodoxe, în rev. „Ortodoxia”, anul XXXIV, nr.1, 1982, p.55.

${ }^{2}$ Leonid Uspenscki, apud, Teologia icoanei, trad.Teodor Baconsky, Editura Anastasia, 1994, p.17. 


\section{Orthodox icon, medium and the mystical way of communion of man with God through the Holy Spirit}

imposing rules. ${ }^{3}$ By speculating this position it might be believed that Christian art had developed in the Church without considering the Church hierarchy. Klauser places, such as French scientist Gibon, the appearance of icons between 350-400 AD, when, according to the researcher, there had been a general change of the Church's attitude concerning imagery.

The view that, like the Jews, early Christians refused religious pictures, primarily due to the absence of images in the first two centuries in archeology's treasury, is seriously undermined by information drawn from apocryphal texts on the life of St. Apostle John, speaking of a portrait of the apostle venerated by one of his disciples ( $2^{\text {nd }}$ century). Also, the first image of the Virgin Mary, traditionally painted by St. Luke, an icon of Christ from Jerusalem painted by the Virgin Mary herself added to the cult of relics, well known at that time can be considered valuable evidence regarding the existence and development of the cult of images in the first two centuries of Christianity. All these legends, as Andre Grabar called them, testify to the high spiritual value that Christians assigned to religious images in Antiquity. ${ }^{4}$

It is quite possible that the views of the mentioned scientists, that seem to agree with a kind of primary iconographic vacuum, base upon the historical appreciations of Origen and Eusebius, known themselves

\footnotetext{
${ }^{3}$ Apud. Ibid.

4 Andre Grabar, Iconoclasmul bizantin, trad. Daniel Barbu, Editura Meridiane, Bucureşti, 1991, pp.30-33. One may recall here the first icon of Christ, made by divine will, that is not made with hands, and known in the West as the " Holy Face ".It is the Pure Face which, according to the tradition, Christ sent to the King Abgar to cure him of the disease that upset him (this event is reminded in the eighth voice during the Vespers' sticheron August). Although Christian images of the first two centuries and were not very numerous, from the $3^{\text {rd }}$ century they vastly multiply: numerous frescoes on the vaults and walls of the catacombs in Rome, Naples and other places, sarcophagi decorated with figurative reliefs, lots of murals with religious themes in Christian churches, baptisteries, mausolea from different cities (Ravenna, Thessaloniki, Rome, Naples, etc.), images of Christians ordered by Christians and realised by talented artists. It is also a plausible supposition that friends and enemies of icons lived together without being conflictual, tolerating each other. Ibidem, pp. 34 şi 62 .
} 
as Fathers of iconoclasm ${ }^{5}$, according to some authors. Origen talks about the possibility of contemplation of God, without a face, and Eusebius writes somewhat outraged to empress Constantia: ," What kind of icon of Christ are you looking for? True and unchanging face, the one wearing the characteristics of Christ by nature, or that face which he assumed for us when he dressed as a servant? [...] I think you ask, of course, for his face as a servant, the body that he took for us. Now we have learned that it's mixed with the divine glory and that what is mortal has been swallowed up by life." 6 In other words, Eusebius argues that it is impossible to portray Christ's pneumatized body, absorbed, "swallowed" by the glory of God. But precisely these arguments demonstrate the existence of Christian iconographic image, ${ }^{7}$ which provoked different debates. Among the voices challenging iconographic image can be mentioned those of the Parents from the Council of Elvira, Spain (the year 300), statements of Epiphanius to Salamis, opinions of Minuciu Felix ${ }^{8}$.

But the Christian tradition combats the idea which supports thelate emergence of Christian art. Tertullian (220 A.D.), for example,

${ }^{5}$ Cristoph Schonborn, Icoana lui Hristos, trad. Vasile Răducă, Editura Anastasia, 1996, pp.44-52.

${ }^{6}$ Cristoph Schonborn, apud ibidem, p. 53.

${ }^{7}$ Eusebiu de Cezareea, Istoria bisericească, P.S.B., nr.13, trad. T. Bodogae, Editura Institutului Biblic Şi De Misiune Al Bisericii Ortodoxe Romane, Bucureşti, 1987, p. 288.

${ }^{8}$ Andre Grabar, op. cit., pp.41-44. Several pagan and Christian authors are cited by the author who defend the existance of images. To the religious images typical for the first Christian centuries, also belong the statues. We know that most of the pagan deities were represented by statues. However, knowing this, the early Christian apologists despised honoring statues, their cult being considered erroneous and deceptive. In this respect, Minuciu Felix, great apologist and philosopher of the primary period, baptized under the name Mark, believes worship of the gods (their statues are things made by human hands) a degradation of human dignity, Greek mythology itself being ,, false '.If the sacred art primarily means both icon and statue, seen as religious images, Minuciu Felix, presented by Andre Grabar as a voice that rises against the sacred image disputes in fact the illustration of divinity in the form of statues, as in the case of pagans, and not the actual icon). Minuciu Felix, Dialogul Octavius, P.S.B., Nr.3, „Apologeţi de Limbă Latină", trad. Nicolae Chiţescu, Eleodor Constantinescu, Paul Papadopol, David Popescu, Editura Institutului Biblic Şi De Misiune Al Bisericii Ortodoxe Romane, Bucureşti, 1981, pp. 373-376. 


\section{Orthodox icon, medium and the mystical way of communion of man with God through the Holy Spirit}

says that the early Christians had printed on different household dishes images of the Good Shepherd, ${ }^{9}$ the first iconographic images (Old Testament stories) being found on the graves of martyrs around 200 A.D., suggesting that the iconography was already clearly an integral part of these Christians' religious cult.$^{10}$

For us, Orthodox Christians, it is very important to understand if these testimonies, for or against the religious art, were compatible or not with the doctrine revealed by Christ. It is very likely that in the early Church, the views of Christians upon the possibility of having icons were contradictory, but this might have been the result of the confusion that governed the attitude of Christian novices, who were confronted with a new law which shed a new light on the teachings of the Old Testament, meaning of which have not been yet entered. A possible primary motivation for this confusion would be the absence of suitable oral and picturesque landscape. ${ }^{11}$ The difficulty with which Christians tried to understand and express the transcendent reality, historical, social and religious conditions specific for those times formed a complex of problems that could easily arise a lot of confusion, even in the cult of icon. This is the main reason why the early church addressed to the world, a new world that had to get used to the reality of the Incarnation, making use of Christian symbols, whose language was more accessible to the faithful than the direct image, these religious symbols being counted as ", food for the deciduous teeth specific to childhood .",12

Religious symbols speak for themselves about the meaning assigned to them in the early Church: The representation of Our Lord in

${ }^{9}$ Cristoph Schonborn, apud, op.cit.,p.53.

${ }^{10}$ Nicolae.V. Dură, op.cit., p.55.

${ }^{11}$ L.Uspenscki, op.cit., p.19.

12 L.Uspenscki, ibid. A plurality of images have been preserved from the time of the first three centuries, either carved in bas and alto-reliefs on sarcophagi or painted. We find representations of the Good Shepherd, dated early in the $1^{\text {st }}$ century, in order to constantly update in the mind of the worshippers the words of the Saviour : ,I am the Good Shepherd" (John.10,14), or: „I came to the lost sheep of the house of Israel "( Mt.15, 24), and their meaning: lifting the fallen human nature (symbolized by a lamb raised on the shoulders) by Good Shepherd, image showing the world a truth of faith . 
the guise of Orpheus with a lyre in hand, surrounded by animals; vines, very common in the first centuries: ,I am the vine, ye are the branches' (John 15,5); fish symbol, widespread ,Follow me and I will make you fishers of men' (Mark 17), the unique meaning of this symbol being covered by the letters making up the word Ichtus ${ }^{13}$; symbol of the lamb, etc.$^{14}$

From what has been set up here we can deduce that iconographic art expresses, above all, the Church's teachings and corresponding sacred texts. Its purpose was not historical, not intended to perpetuate the historicity of the represented character, but to preserve, protect and keep the transmission of the Christian faith and the revealed divine message unaltered.

Despite the existence of certain expressions in the Church, that were hostile to images, primarily due to confusion caused by the novelty of transmitting the message of the Christ, tradition removes any doubt about the basis and use of the icons from the beginning as a means of knowledge and contemplation of God, sanctifying our lives and the world. If Christian symbols from the first centuries were intended for a small number of initiates, starting with the Constantinian age and following the Edict of Milan (313), with the increasing number of converts, symbols are gradually given up, courage, freedom of belief is expressed directly through icons in the form of monumental paintings representing the classical form of Orthodox icons. These pictorial images are the result of that living Christianity, in which dogma and life are identified.

\section{Grounds venerating icons}

Idolatry returned was one of the arguments most frequently used by iconoclasts against iconophiles. Reasons getting your opponents to consider cult icons iconography as an idolatrous practice are multiple .Hellenization superficial Jews in the lands of Asia Minor, Hebrew whose

\footnotetext{
${ }^{13}$ Iesous Christos Theau Uios Soter = Jesus Christ Son of God Savior.These words are a short symbol of faith

${ }^{14}$ L.Uspenscki, op.cit., p. 39.
} 


\section{Orthodox icon, medium and the mystical way of communion of man with God through the Holy Spirit}

attitude vis-a-vis the veneration of images is well known, the refusal of the Armenian Church to accept the teachings Christological promoted Synod Fifth Ecumenical Council of Chalcedon in 451, which led to hostilities of Armenian monks regarding iconographic representation, the emergence of new teaching sectarian of pavlicienilor and Manichees, political interests or sentiments of kings are just some of the main causes that sparked iconoclasm under Basileus Byzantine Leo III. Different conceptions images, iconoclastic unassigned a symbolic icon, limited to only one portrait and arguments expressing divinity unable representation of God, generated heated disagreements between the two sides. As such, the king commanded iconoclasts were persecuted both icons and defenders. VII Ecumenical Council settled cult icon, but not a developed doctrine.Fathers still works falls short of disputes on the possibility of honoring the icon, their arguments paving the way for the triumph of Orthodoxy (843) from the time the Empress Theodora.Their impressive theological and apologetic work helps us, people today to understand better the reasons, rationale underlying the existence of religious icons and worship them. Handy to all our best to convince ourselves of this truth.

\subsection{Biblical grounds}

Ever born of the Father, the Word of God, natural image of His Father (Colossians 1:15), created man in His image and likeness (Fac.1,26) forged it with his holy hands. ${ }^{15}$ Man has become so being the choicest of the universe, image (icon) of God. Moreover, as we shall see, God revealed and manifested in the world created by Him through icons symbol, revealing Himself in the most exalted icon icons Christ, who could be seen and heard. That's saying and we can call on God, His Son Protochipul iconography supreme creation.

Ontologically, the man is destined sanctification and deification ${ }^{16}$. After fell from the initial gracious, disobedience, has led

${ }^{15}$ Clement Romanul, în „Scrierile Părinţilor Apostolici”, Bucureşti 1979, p. 63

${ }^{16}$ Deification is a mystery that reaches the human person and is done by divine grace. Attaining this state is the goal of human life is possible through our collaboration with 
to the harbor for redemption, the slow-put by the symbols and then, at the proper time by icons. The second commandment of the Decalogue, atât often used against cult images, appears so misinterpreted. It's true that Moses po-pore prohibits its resemblance to do a thing that is in heaven, on earth, in water or underground, and into China these human creations (Exodus 20.3), but he also it is that obeying the Lord commanded to make the image of cherubs, the ark and all that is in the tent, for Solomon to build a temple of God in which are carved around cherubim (1 Kings 6,25, 29). In this case, contradicting Moses, Solomon, or God? Why ban honoring chips made with hands must be understandable given the divine pedagogy. Knowing God tilting human nature to $\sin$ in protected man or sought to beware of idolatry by the command not be allowed to represent the image perceptible any likeness of any thing in this world to worship (Exit 20.4 to 5), but nevertheless he made his presence felt using the created nature.For this reason, the tools did God use to in-tra about man have always been considered sacred, a place of divinity presence, being in high esteem.

Various objects or things that the Creator communicate with people are nothing but symbols around which held sacred religious life of the faithful. They mingled with God, in the sense pantheistic, but had the role of signs, guiding man to supernatural and pointing to it as far as a man could perceive some of the attributes of God, such as omnipotence, will, omnipresence, His existence. The Old Testament symbols not imagined image of God, He can not be seen, but headed rpm tea to him. Need picture of something concrete was felt then as an impulse of faith to him that had an intimate connection with the sacred, but the state of infancy spiritual they were Jews at that time did not allow a mature understanding of how honoring the divine image, if they would be shown. This weakness was demonstrated otherwise by themselves by picking up the golden calf in the wilderness of Sinai, real-ity anticipated divine omniscience. For these reasons God gave a

Christ free. It is the state of coexistence with Christ, admirably expressed by the Apostle Paul: ,no longer live, but Christ lives in me” (Galatians 2.28). Deification is union with God, His secret knowledge. Olivier Clement says: „Man is really only deified man." View: Olivier Clement, Puterea Credinţei, trad. Alexandrina Andronescu şi Daniela Ciascai, Editura Pandora, Târgovişte, 1999, p. 74. 


\section{Orthodox icon, medium and the mystical way of communion of man with God through the Holy Spirit}

command prohibitive in terms of image representation, temporarily, a law suitable for the uninitiated in the religious novices and imperfect.

Just as the Old Testament is ,, shadow" of the new law, it is perfect, and the symbol is the prototype icon Old Testament New Testament. „Although it may seem strange, says Leonid Uspenscki for Church sacred image follows precisely the absence of direct image in the Old Testament; First is the consequence and completion of the other. The prototype image Christian is not pagan idols, such as reckoned sometimes, but the absence of the symbolism of the Old Testament any concrete images and outspoken before the Incarnation, just as the prototype of the Church is not the heathen world, but ancient Israel, God's chosen people to receive revelation .",17

Measure pedagogical cautious of God forbidding, on the one hand, enable direct imaging, on the other hand commanded the symbolic embodiment building stands out from even uttering divine speech : „I gave statutes that were not good "'(Jezechil 20,25). These laws will be less good perfect Son of God in the Incarnation, so iconographic representation, for example, will be allowed and the many, not just those selected. In the Old Testament could not be only symbolic foreshadowing of what the future would bring, they are ,shadow of the future and not the very image of good "' (Hebrew 10,1), the image scale is only fully expressed in the New Testament. Negation stops to be like God created a creature (sun, moon, stars, animals, etc.), yet Israel is raised to the contemplation of God through symbols placed by Moses in the holy tent. If the Old Testament God only heard communicating with humans only by word and symbols with the same supernatural revelation God reveals world both in word and picture. Now he can be heard and seen (Matthew 13: 16-17; Luke 10, 23-24), because the Incarnation sight and hearing became inseparable .

The icon is not imagine divinity. Glory to God (Gottes Herrlichkeit) we can not comprehend the artistic or color. Seeing God in His essence is impossible with man (John 1:18; 1 John 4:12). This, however, does not shut it off in the Creator is shown to the eye and the

${ }^{17}$ L. Uspenscki, op.cit., p. 20. 
human mind in various forms: the image of the three travel from Mamre (Genesis 18,6$)$; in directly he appeared to Jacob, who saw his face (Gen. 32.30); in the form of bush burning and not consumed (Gen. 3.4); dove appeared to Ioan Botezătorul (Mark 3:16; Luke 32.22); the blinding light appeared to Saul on the road to Damascus (Acts 9.3); and so on.

Therefore God has forbidden icon, the image of His holy Graven image is an icon, and prohibition was a measure to protect people divine teaching Hebrew naive error from the true faith. Precisely for this reason God allowed symbol Old Testament, to stop idolatry and human thought to ascend to the invisible. Incarnation of the Word of God brought to light in the human mind, seeing and touching it literally the Man Jesus understood purpose and possibility icon . Astfel, icoana devine semnul văzut al prezenţei tainice a lui Hristos. She not only thought going to heaven, but we also show him who dwells in heaven, then ,,and like help our word as to rise above the word, so we use that icon to rise above icon. And as God wants us to be holy hearing by pure words, like so as to be sanctified through our pious icons as through both senses into the soul superior to pure thoughts ." 18 Icon put so closely connected reality of both worlds, always honoring the prototype represented worshiper.

\subsection{Dogmatic basis}

When the time came, God's Word, the divine Logos, became incarnate by the Holy Spirit and the Virgin Mary, becoming man. Once incarnate, the world would see Him, the Unseen, looking at His Son Jesus Christ, the Son of Man. Symbols and prophecies of the Old Testament anticipated His supernatural revelation, preparing gradually for receiving and accepting it, for the mystery of conception in the womb of the Virgin brought the world the possibility of salvation, the Savior's face being able to be seen, heard and immortalized in images. The Unrepresented thus became representable ,,by dwelling Himself in human flesh to be displayed in it. ", 19 .

${ }^{18}$ Ilie Cleopa, Călăuză în Credinţa Ortodoxă, Galaţi, 1991, pp. 98-99.

19 Atanasie cel Mare, Tratat despre Intruparea Cuvîntului, P.S.B., nr.15, trad. 


\section{Orthodox icon, medium and the mystical way of communion of man with God through the Holy Spirit}

Orthodox apologists of icons have argued and documented varied position on the iconological issue sparked during the iconoclastic period, but the roots of all their arguments are firmly anchored in the great mystery of the Incarnation of the Word of God. The argument of the Incarnation is so important that renowned theological researchers define iconoclastic heresy, in essence, as Christological, which indicates that iconomachs hitting with zeal and passion the grounds of sacred art, punched in fact blindly the Savior's person, the open struggle against icons gradually turning into a fierce antichristic battle, the followers of the position contrary to the veneration of icons even being named christomachs.

Through the Incarnation the human face becomes theophanic, so the icon is an "anthropomorphic deity" which testifies the divine presence. Conversely, wanting to deny the fundament of the icon, iconomachs claimed that to represent Christ means ,to lower Him down and to shrink Him ," 20 suggesting His contemplation only with the mind, the Holy Spirit dwelling into those who struggle to gain likeness of God through holiness and righteousness ${ }^{21}$ St. Theodor The Studite allow modeling of man through the Holy Spirit, a modeling of the mind that immediately succeeds Baptism and lasts until the death of the body, during which the image of the hypostasis of God the Father is imprinted in the mind of man, but this modeling couldn't be achieved if the face of the Father hadn't been incarnated and if one would not think of Christ and his saving deeds. The mental contemplation is mediated by Christ, the incarnate Logos.$^{22}$

God formed dust and created man in His image (Genesis 12:6), and in the fullness of time He offered Himself as a visible model to be heard. Thus by seeing Him we can follow his acts, by knowing Him we

D.Stăniloae, Editura Institutului Biblic Şi De Misiune Al Bisericii Ortodoxe Romane, Bucureşti, 1987, p.93.

20 Teodor Studitul, Antireticul I, în rev. „Studii Teologice”, anul XXXI, nr.1-4, 1979, p.12.

${ }^{21}$ Ibidem.

${ }^{22}$ D. Stăniloae, Hristologie şi iconologie în disputa iconoclastă din secolele VII-IX, în rev. ,Studii Teologice”, anul XXXI, nr.1-4, 1979. 
can serve Him. His icon becomes modeler of our entire being. Prefigured by the symbols of the Old Law, through which the man acquired a reduced, obscure knowledge of God, He only being revealed to mankind like shadows, Christian icons depict Christ incarnate for those who were not his contemporaries, ,expressing this great increase in the knowledge of God ."23 The sight of Christ in the icon precedes His contemplation, for if this kind of mental contemplation had sufficed, He would have reached us only this way, says St. Theodor the Studite, ${ }^{24}$ avoiding the Incarnation, Passion, Death, Resurrection, Ascension . But because His incarnation is real, the icon enables us His contemplation and the communication with Him through the Holy Spirit, for by becoming incarnate, the Son of God circumscribed Himself by time and space for a while, becoming like us. This makes the representation in images possible, because we too, the ones from today, have to see the Saviour, strengthening our faith in him. The icon exceeds the materiality of the world, the mankind turning its mind to the spiritual world. Even the divine disciples have seen the Lord first and only afterwards recorded His Word in written form.

The fact that Christ was man is undeniable, and this truth speaks about His willingness to circumscribe, about His love for people which touched Him so much that he became incarnate to save us. ${ }^{25}$ Incarnation as a result of His love, is what Orthodox theology calls kenotic manifestation of God: the supreme act of divine humility and the main dogmatic argument allowing the possibility of painting Him in icons. The Logos took human form and he filled it with His divine light. This illuminated Face of Him is the icon we worship.

\subsection{Anthropological basis}

Man was created by God through a special act, being brought into existence as a unit composed of body and soul. The human being is

\footnotetext{
${ }^{23}$ D. Stăniloae, Simbolul ca anticipare şi temei al posibilităţii icoanei, în rev. „, Studii Teologice", anul LXXV, nr. 7-8,1957, p. 429.

${ }^{24}$ Teodor Studitul, op.cit. p. 12.

${ }^{25}$ Atanasie cel Mare, op.cit., p. 93.
} 


\section{Orthodox icon, medium and the mystical way of communion of man with God through the Holy Spirit}

not a simple or, according to some a complex work of nature, also created before him, but by being formed from dust it is connected with it. The biblical Genesis tells us that God made man simultaneously and not after a temporal succession, an idea that supports that the body had been created first and then the soul, or vice versa. Taking the dust out of the earth, God breathed the breath of life into the nostrils of the thus created body and made him a living being (Genesis 2.7). This special act of the creation of man distinguishes him from the rest of nature and other existence forms created in the universe. God made flesh by 'taking the dust of the earth' and didn't command the earth to produce it, as in the case of the other creatures, gave man the power to fulfill His desire. In the act of human creation, the direct, proximate intervention of God is evident. As such, the human being has a special position not only towards the nature out of which it was made, but also towards God, the body being linked to nature, matter while the soul is in the most intimate connection with God. As land we belong to nature, through our soul transcend it.

Through the special act of creation an indestructible, living relationship was born between man and his Creator, fundamental and expressed through the reality of the image of God in man , ${ }^{26}$ "face", altered then because of the original sin. This relationship, conscious and free, puts man in constant communion with his protoface, which means a continual sharing of God's grace. Father Stăniloae, talking about this relationship, considers the strong human desire towards his Creator as natural as possible, since our soul is akin to God. Now our kinship with God ${ }^{27}$ makes us appear like living icons of God in His creation.

26 The image of God in man is essentially defined by reason, feeling and will, spiritual attributes of human beings with which one can acquire ,likeness" of God. Without possessing this face, the human being can't freely tend to moral perfection, „face” being an ontological gift to man, that is precisely the divine element inserted to the human nature through creation because of whose existence we can say that man has something conatural with the divine. See impressive works of theologian Panayotis Nellas, Omul - animal îndumnezeit. Perspective pentru o antropologie ortodoxă, trad.Ioan. I.Ică jr., Deisis, Sibiu, 1998.

${ }^{27}$ One may not understand a relationship with the divine in the pantheistic sense. The 
Through the supernatural way of our creation, th image of divinity is revealed to the entire creation, in the world and in the mankind. Leonid Uspenscki reminds us of the cosmic meaning of man, the man as microcosm being the center of created life, the route and means by which God acts upon the creature and the creature participates into spiritual life : „,Placed by God before all the seen creatures the man should realize in himself the harmony of the whole, uniting the whole with God, making the universe a homogeneous body, in which God would be - everything in all - for the ultimate goal of creation is its transfiguration.,"28 This is the main reason why the Catholic and Ortodox Churchs worship the cult of saints.

As an image of God, man is by creation a living icon of Him. It is however true that the light of Christ doesn't transpire (isn't reflected) with the same intensity for all men. Deification being the ultimate goal, every man must undergo the own spiritual ascent to become a living bright icon of the godly light.

The anthropological basis of the existence of icons lies in the quality of the human being to be ,related " to God, that is to be created in His image. This is in fact also the main argument why the Son of God incarnated and took human form: $\mathrm{He}$ is the natural icon of the Father (Colossians 1:15). If with the fall of the forefathers the image of God in man was altered, deformed, the best solution was to let Jesus Christ, the image (icon) of the Father, restore the image of God in the fallen man. So Father's perfect face restored, saved, straightened the face of the fallen man. In other words, the image in whose likeness we were created, meaning the Word incarnate, Christ, saved us. And this image is not an idol, but the true icon of God the Father. We worship and venerate it.

The Son of God is the model (the uncreated protoface) after which man is created. Therefore we say that God is the first creator of icons and we believe that the living or painted icons created by us express the power to create which we received from the same God.

statement emphasizes the reality and presence of God's image in man, quality that defines the greatness of man in the universe.

${ }^{28}$ L.Uspenscki., op.cit.,p. 108. 


\section{Orthodox icon, medium and the mystical way of communion of man with God through the Holy Spirit}

\subsection{The difference between idol and icon}

Although apparently it could be understood that the Scriptures contradict themselves, given on one hand the prohibition of any representation, on the other hand the commandments that urged building faces of the cherubs, in reality this is not so, those who reject icons, reckoning them as idols, committing great and unfair confusion. Firstly, in the Holy Book there is a categorical difference between idols and icons even concerning words used in each of these elements. Thus, the term used to define an idol is the,, graven image ", showing the material of which it is made . „Do not make a graven image, any likeness of any thing ... '(Exodus 20, 4); „,Do not make a mistake and do not make a graven image or the likeness of an idol ... "'(Deuteronomy 4:16 ); „Take care not to forget the covenant of the Lord your God that He made with you and do not make for yourselves idols of anything ... " (Deuteronomy 4,23); „But he returned the silver to his mother. And his mother took two hundred shekels of silver and she gave them to a silversmith who used them to make an idol and it was put in the house of Micah " (Judges 17.4 ); are some biblical arguments in this respect ${ }^{29}$ At the same time, the Scripture uses the term "face" to mean something different than the graven image or the idol, that is precisely the meaning of the icon. For example expressions like: „So God created mankind in His image ” (Gen. 1,27); „A man ought not to cover his head, since he is the image and glory of God ... "'(1 Corinthians 11: 7 ); ,and have put on the new self, which is being renewed in knowledge in the image of its Creator " (Colossians 3:10), clearly shows the idea of icon and not of an idol.$^{30}$

Following the thread of these arguments, it can be seen that the idol or graven image is always put in relation with false gods, produced by human imagination and the face - as an image - is in a natural

${ }^{29}$ See also: Deuteronom.5,8; 7.25; 12.3 27.15; Judecatori.17,4; 18.14, 2 Chron. 33.7; Jeremiah. 10.14; Isaiah 10:11..

${ }^{30}$ See also: Romani.8,29; 2 Cor. 3.18; Evrei 1,3 . 
relationship with the living and undeceitful God. These differentiating names show the cause of prohibition of images in the Old Testament, which is of pantheistic origin specific for the man banished by God, one who understands the world as an ultimate reality, for whom transcendence and immanence are the same. This reality has led and still leads, especially in the case of natural religions, to the worship of nature, the idol appearing as a face (picture) of some forces of nature, often symbolized by a human or semi-human form. ${ }^{31}$ In this way, the warmth of the sun was embodied in the image of the sun, the reproductive force of life was symbolized by the image of bull and of the cow, the sea water took the human form of the god Neptune, beauty and physical love was embodied by the goddess Venus, etc. But all these gods are pieces made of nature identified with God. Their worship doesn't transcend nature of which they were composed, in which they are circumscribed forever. Now, precisely therein lies the radical difference between idol and icon. The icon doesn't close in nature, like the idol, but opens our being to the supernatural. The belief in a higher reality and the will to overcome nature is the fundament of worshipping icons, the icon completely distinguishing the natural level from the divine one, the worshiper always seeking the touch with the reality beyond the icon.$^{32}$ The icon opens to mankind a way of communication with a supericonic reality, being the visible and material form which can provide us the happiness of living an existence beyond sight and sense.

If the idol can be identified sometimes with the god himself, the icon shows a spiritual reality that is not the same, because it is neither the idol that gathers within itself all the forces of nature, nor the symbol of the Old Testament which was confirming the presence of God, attesting the distinction from Him, but the representation of God Himself. ${ }^{33}$ The human being, becoming the radiant light of the image of God can be considered a symbol of divine transcendence, he is currently in Christ, from Baptism, whom he shows, but whom he

31 D.Stăniloae, Idolul ca şi chip al naturii divinizate şi icoana ca fereastră spre transcendenţa dumnezeiască, în rev. „Ortodoxia”, Anul XXXIV,nr.1,1982, p. 13.

${ }^{32}$ Ibid, p. 17.

${ }^{33}$ Idem, Icoanele în cultul ortodox, în rev. „, Ortodoxia”, Anul XXX, nr.3, 1978, p. 476. 
doesn't identify. The icon appears as a safe place of God's presence, be it the icon painted on the material, be it embodied by the living icon that is the man himself.

Icon and mankind are part of the created world, world which can be regarded as an idol, when considered as the ultimate reality of existence, without the basic landmarks of transcendence, or can be understood as a symbol of divine transcendence, showing its cause and finality in God. The important thing to remember is that man is a being meant to transcend nature, for although $h$ does note is in it, he doesn't remain in it, and the icon helps him to make this priceless spiritual step.

\section{Conclusions}

1. Our Lord Jesus Christ,,wants all men to be saved and to come to knowledge of the truth " (1 Timothy 2.4), His mission of becoming known being entrusted to His Church, whose head He is. The isolation of God in the transcendent or denying His existence does not solve the set of problems the secularized human society is confronted with, the world as whole, for which the salvation as the supreme gift of God, is, unfortunately, a mere private alternative.

2. Homo religious, with the scientific and technological revolution, has changed its features in those of homo otiosus: egocentric, autonomous, formalist, lascivious. The new man, formed in and by modernity has shaped its fresh "ethical" profile so that he can recommend himself as a being substantially circumscribed from the materiality of the world he survives in, uninterested of holiness and perfection in God. His concerns tend more and more to zero in terms of his relationship with Christ. His world is governed only by money, material success and desire to satisfy all his biological pleasures. It is a world ruled by gods, magic, passion, other than the one created by God, a world that darkens Him and plunges the whole of creation, the whole universe, into opacity and death.

3. In such a secular world, where people appreciate only what they see, ignoring the existence of the spiritual universe, invisible, in which the 
human eye, deprived of the divine light, observes around itself a beautiful and wonderful material world but doesn't see its real sense in which our hearing, confused by so many and so many lustful screams, no longer perceives the mysterious, soft, suave voice, of the creation, the Icon, this „miracle of faith ", appears on the horizon to which our life flows (fließt) as the sanctifying image that unleashes the latencies of the human soul, thus becoming the spiritual eye that is so needed to see the transcendent world, to know and contemplate it. It really appears as a window ,, " that not only directs the minds to the world beyond, but offers the real means of mystical communication between man and God.

4. The basis of the worship of icons that justifies their cult, offering already from the beginning of Christianity the possibility of iconological theologization, is the biblical and dogmatic fundament of the icon. We could not speak of icon if the very Son of God, the Word and natural icon of the Father (Colossians 1:15) had not incarnated and hadn't taken human form. But through the Incarnation, the man created by God in His image, becoming "an icon of divinity ", wanted to achieve through imagery the face of his Savior. Without being wrong we can say that in the beginning was the icon.

\section{References:}

1. Eusebiu de Cezareea, Istoria bisericească, P.S.B., nr.13, trad.T. Bodogae, Editura Institutului Biblic Şi De Misiune Al Bisericii Ortodoxe Române, Bucureşti,1987.

2. Grabar, Andre, Iconoclasmul bizantin, trad.Daniel Barbu, Editura Meridiane, Bucureşti, 1991.

Rămureanu,I,. Cinstirea sfintelor icoane în primele trei secole, în rev. ,Studii Teologice”, nr. 9-10,1971.

3. Dură, V.Nicolae, Teologia icoanelor în lumina tradiţiei dogmatice şi canonice ortodoxe, în rev. , Ortodoxia”, anul XXXIV, nr.1, 1982, p.55.

4. Schonborn, Cristoph, Icoana lui Hristos, trad.Vasile Răducă, Editura Anastasia, 1996.

5. Uspenscki, Leonid, Teologia icoanei, trad.Teodor Baconsky, Editura Anastasia, 1994. 
Orthodox icon, medium and the mystical way of communion of man with God through the Holy Spirit

6. Sfântul Ioan Gură de Aur, Cuvântări la praznice impărăteşti, trad. D. Fecioru şi O. Căciulă, Bucureşti, 1924.

7. Stăniloae, Dumitru, Idolul ca chip al naturii divinizate şi icoana ca fereastră spre transcendenţa dumnezeiască, în rev. „Ortodoxia” anul XXXIV, nr.1,1982.

8. Lialine, C.Dom, în rev. ,Irenikon”, t.XI, 1934.

9. Fecioru, Dumitru, Teologia Icoanelor la Sfântul Ioan Damaschin, în rev. ,, Ortodoxia” anul XXXIV, nr.1, 1982.

10. Branişte, Ene, Teologia Icoanei, în rev. „Studii Teologice” anul IV, nr.3-4, 1952. 